\title{
Lög og bókmenntir í íslensku samhengi
}

Ekki er daglegt brauð að nýútkomnar íslenskar skáldsögur og ævisögur komist í fréttir eða veki víðtækar umræður á síðum dagblaða og í netheimum. Eftirminnileg dæmi um petta frá síðari árum eru verkin Halldór 19021932. Avisaga Halldórs Kiljans Laxness (2003) eftir Hannes Hólmstein Gissurarson, Konan við $1000^{\circ}$. Herbjörg María Björnsson segir frá (2011) eftir Hallgrím Helgason og Útlaginn (2015) sem Jón Gnarr skrifaði í samstarfi við Hrefnu Lind Heimisdóttur. Að miklu leyti snerust deilurnar um bók Hannesar um meint brot á lögum um höfundarétt á meðan deilurnar um hinar bækurnar snerust um meint brot á lögum um friðhelgi einkalífs og ærumeiðingar. Dómsmál var höfðað vegna bókar Hannesar sem endaði með pví að hann var dæmdur til að greiða Auði Laxness, ekkju skáldsins, 1,5 milljónir fyrir brot á höfundarétti og 1,6 milljónir í málskostnað. ${ }^{1}$ Hins vegar var hvorki Hallgrími né Jóni stefnt vegna skrifa sinna enda í báðum tilvikum óljóst hverjir aðrir ættu par beina aðild að málum.

Pessi prjú verk eru til marks um að heimar bókmennta og skáldskapar geta skarast margvíslega við lög og rétt. Slíkt eru ekki ný tíðindi fyrir íslenska lesendur sem hafa í aldaraðir haldið upp á miðaldatexta á borð við Brennu-Njáls sögu, Ljósvetninga sögu og Hrafnkels sögu par sem lagadeilur og málaferli eru ein meginuppistaðan og lögspekingar eru söguhetjur. Vangaveltur um tengsl pessara og fleiri sagna við okkar elstu lögbækur, svo sem Grágás og fónsbók, urðu snemma gildur páttur í albjóðlegum fornsagnarannsóknum, ekki síst meðal býskra fræðimanna á nítjándu öld. ${ }^{2}$ Á síðustu áratugum hefur pessi rannsóknarhefơ gengiðí endurnýjun lífdaga, meðal annars fyrir tilstilli bandaríska bókmenntafræðingsins Theodores M. Andersson og landa hans, lögfræðingsins Williams Ian Miller. ${ }^{3}$

1 Hrd. 211/2007.

2 Sjá meðal annars Karl von Lehmann og Hans Schnorr von Carolsfeld, Die Njálssage insbesondere in ibren juristischen Bestandtheilen: Ein kritischer Beitrag zur altnordischen Rechts- und Literaturgeschichte, Berlín: R.L. Prager, 1883.

3 Sjá meðal annars Theodore M. Andersson og William Ian Miller, Law and Literature in Medieval Iceland, Stanford, CA: Stanford University Press, 1989. Bókin 
Jafnframt hefur orðið til athyglisverður flokkur sögulegra skáldsagna par sem efniviðurinn eru málsskjöl um íslensk sakamál frá fyrri tíð. Pekktasta verkið af pessu tagi er líklega Svartfugl. Skáldsaga um Sjöundármálin (1938) eftir Gunnar Gunnarsson en hún kom upphaflega út á dönsku árið 1929. Af öðrum slíkum sakamálasögum má nefna Íslandsklukkuna (1943-1946) eftir Halldór Kiljan Laxness, Yfirvaldið. Skáldsaga eftir bestu heimildum og skilrikjum (1973) eftir Porgeir Porgeirsson, Dauðamenn. Söguleg skáldsaga (1982) eftir Njörð P. Njarðvík og Grámosinn glóir (1986) eftir Thor Vilhjálmsson. Nýlegt dæmi af pessu tagi í íslenskri bókmenntaflóru er Náðarstund (2014) eftir áströlsku skáldkonuna Hannah Kent í pýðingu Jóns St. Kristjánssonar. Sagan kom upphaflega út á ensku árið 2013 undir titlinum Burial Rites og vakti athygli víða um heim en viðfangsefnið er að hluta til pað sama og í sögu Porgeirs, pótt efnistökin séu ólík.

Að auki hafa ótal lögfræðingar, dómarar og sakborningar skotið upp kollinum í fjöldamörgum íslenskum skáldverkum, ekki síst í peirri bylgju glæpasagna sem hafa komið út hér á landi síðustu tvo áratugi. Í sumum pessara verka eru glæpir og refsingar beinlínis í brennidepli. Hér er um að ræða hefð sem nær að minnsta kosti aftur til fyrstu áratuga tuttugustu aldar. Má í pví sambandi minna á ýmis leikrit Guðmundar Kamban, ekki síst Marmara (1918) par sem meginviðfangsefnið er dauðarefsingar. Af nýlegri verkum má nefna skáldsögurnar Ég heiti Ísbjörg, ég er ljón (1989) eftir Vigdísi Grímsdóttur, Kötu (2014) eftir Steinar Braga og Gott fólk (2015) eftir Val Grettisson sem allar eiga pað sameiginlegt að fjalla um ofbeldi karla í garð kvenna og tilraunir einstaklinga til að taka lögin í eigin hendur. Á seinni árum hefur opinber meðferð margvíslegra mála par sem kynferðisleg áreitni, misnotkun og nauðganir koma við sögu sætt harðri gagnrýni og hefur athyglin beinst meðal annars að lagarammanum og pætti lögreglu og dómstóla. Verk skálda og rithöfunda eru veigamikið innlegg inn í pessa umræðu sem í eðli sínu snýst um grundvallaratriði: lög og rétt, glæp og refsingu.

Erlendis hafa pverfaglegar rannsóknir á sviði laga og bókmennta verið blómlegar á undanförnum áratugum, ekki síst í Bandaríkjunum, en rannsóknarhefðin par er gjarnan rakin til seinustu áratuga nítjándu aldar. Árið 1882 sendi lögfræðingurinn Irving Browne (1835-1899) frá sér mikið rit,

hefur að geyma enskar býðingar peirra á Ljósvetninga sögu og Valla-Ljóts sögu, ásamt ítarlegum inngangi og athugasemdum. Nánar er fjallað̆ um viðamikil skrif Millers um íslenskar fornbókmenntir og lög í inngangi að grein hans aftar í pessu hefti, bls. 39-40. 
Law and Lawyers in Literature (Lög og lögfreðingar í bókmenntum) sem hefur að geyma fjölda sýnishorna úr heimsbókmenntunum (m.a. úr leikritum, ljóðum, skáldsögum og ritgerðum) par sem lög og lögfræðingar koma við sögu. Browne ræðir um hvert dæmi en bók hans er bó nær pví að vera sýnisbók en fræðirit á pessu sviði. ${ }^{4}$ Á fyrstu áratugum tuttugustu aldar mótaðist síðan meðal bandarískra lögfræðikennara hreyfing í kringum lög og bókmenntir (e. the law and literature movement) sem hafði framan af pann tilgang að bæta menntun lögfræðinema. Er hreyfingin gjarnan rakin til bókalista sem John H. Wigmore, rektor við Northwestern University Pritzker School of Law, próaði í nokkrum áföngum yfir skáldverk par sem lög, lögfræðingar og réttarhöld eru meginviðfangsefnið. Wigmore taldi að lestur slíkra verka víkkaði sjóndeildarhring lögfræðinga og dómara og gerði pá hæfari til að sinna starfsskyldum sínum. ${ }^{5}$ Áður en yfir lauk taldi listi Wigmores 100 titla en meðal peirra höfunda sem hann hélt á lofti voru James Fenimore Cooper, Charles Dickens, George Eliot, Robert Lewis Stevenson, Honoré de Balzac, Alexandre Dumas og Lev Tolstoj. Ýmsir hafa orðið til pess að lengja og endurskoða pennan lista á síðari árum en slíkt starf, sem og fjölbreytt umfjöllun um lögfræðilegar hliðar tiltekinna skáldverka, hefur smám saman mótað einhvers konar hefðarveldi (e. canon) á pessu sviði. Pví tilheyra meðal annars leikritið The Merchant of Venice (Kaupmaðurinn i Feneyjum) eftir William Shakespeare og skáldsögurnar Michael Koblhaas (Mikkjáll frá Kolbeinsbrú) eftir Heinrich von Kleist, Mansfield Park (Mansfield-garður) eftir Jane Austen, Billy Budd, Sailor (Sjómaðurinn Billy Budd) eftir Herman Melville, Der Process (Réttarböldin) eftir Franz Kafka, L'Étranger (Útlendingurinn) eftir Albert Camus og To Kill a Mockingbird (Að drepa bermikráku) eftir Harper Lee. ${ }^{6}$

Um miðjan priðja áratuginn færði bandaríski dómarinn Benjamin N. Cardozo annars konar rök fyrir pví að lögfræðingar kynntu sér skáldskap og bókmenntir. Par sem starf stéttarinnar snerist að verulegu leyti um skrif (að semja sóknar- og varnarræður, lög og dómsorð) væri yfirgripsmikil pekking á stíl og stílbrögðum gagnleg hverjum peim sem vildi ná árangri

4 Sjá m.a. John Hursh, „A Historical Reassessment of the Law and Literature Movement in the United States“, Graat 14. júní 2013, sótt 6. apríl 2018 af http:// www.graat.fr/1hursh.pdf.

5 John Henry Wigmore, „A List of 100 Legal Novels“, Illinois Law Review 17(1)/19221923, bls. 26-41.

6 Sjá Richard H. Weisberg, „Wigmore and the Law and Literature Movement“, Law and Literature 21(1)/2009, bls. 129-145. 
í faginu. ${ }^{7}$ Skrif Cardozos og fjölmargra sporgöngumanna hans hafa eflt almenna vitund um að lögfræðilegir textar hafi ýmis bókmenntaleg einkenni en pað er efni sem James Boyd White tók til ítarlegrar umræðu í bók sinni The Legal Imagination (Hið lögfreðilega imyndunarafl) árið 1973. Hún er talin marka tímamót í akademískum rannsóknum á pessu sviði. Á næstu tveimur áratugum urðu lög og bókmenntir að viðurkenndu pverfaglegu rannsóknarsviði í Bandaríkjunum með pátttöku áhrifaríkra lögfræðinga, heimspekinga og bókmenntafræðinga. Í peim hópi eru Richard Weisberg, Richard A. Posner, Martha Nussbaum, Ronald Dworkin, Stanley Fish og Peter Brooks. Ekki leið á löngu par til bandaríska fræðiumræðan fór að hafa áhrif víðar, meðal annars í Evrópu. Staðbundnar lögfræðilegar hefðir og bókmenntir hafa eðlilega mótað rannsóknir í ólíkum löndum en ýmis dæmi eru um hve erfitt getur reynst að skapa raunverulegan umræðugrundvöll milli lögfræðinga og fræðimanna af sviði hugvísinda.

Hér á landi hafa ýmsir fræðimenn sinnt rannsóknum sem unnt er tengja sviði laga og bókmennta. Sterkust hefur hefðin verið í rannsóknum á lagalegum grundvelli íslenskra miðaldabókmennta en pegar hugað er að rannsóknum á íslenskum skáldverkum frá síðari öldum vekur sérstaka athygli samstarf bókmenntafræðingsins Sveins Skorra Höskuldssonar og lögfræðingsins Pórs Vilhjálmssonar. Árið 1969 kenndu peir saman námskeið sem ætlað var nemendum í peim ólíku deildum Háskóla Íslands sem peir kenndu við; Pór var prófessor við lagadeild og Sveinn Skorri nýráðinn lektor í íslenskum bókmenntum við heimspekideild. Í grein sinni, „Játningarnar í Sjöundármálinu“ sem birtist árið 2006, segir Pór svo frá:

Texti pingbókar Barðastrandarsýslu frá 1802 um Sjöundármálið var skrifaður upp af laganemum og síðan dreift til pátttakenda. Pessi texti var borinn saman við pað, sem um réttarhöldin segir í skáldsögu Gunnars Gunnarssonar, Svartfugli, og rætt var um pýðingu pess í bókinni. [...] Afbrotin sjálf voru stórglæpir en í huga greinarhöfundar hefur annað úr pessari morðsögu verið áleitið alla tíð síðan. Eru pað sinnaskipti morðingjanna í réttarhöldunum og játningar peirra. ${ }^{8}$

Benjamin N. Cardozo, „Law and Literature“, Yale Review 14/1925, bls. 699-718. Pór Vilhjálmsson, „Játningarnar í Sjöundármálinu“, Guðrúnarbók: Afmelisrit til beiðurs Guðrúnu Erlendsdóttur 3. maí 2006, Reykjavík: Hið íslenska bókmenntafélag, 2006, bls. 489-497. 
Grein Pórs var síðbúinn ávöxtur námskeiðsins en pað má einnig ætla að efnismikill eftirmáli Sveins Skorra við útgáfu hans af sögu Gunnars frá 1978, par sem dómsmálið frá 1802 kemur nokkuð til tals, hafi einnig tekið mið af samstarfi peirra Pórs. ${ }^{9}$

Hluti af peim íslensku og erlendu bókmenntaverkum sem hér hafa verið nefnd voru viðfangsefni nemenda í námskeiðinu Bókmenntir og lög sem Jón Karl Helgason kenndi á meistarastigi í íslensku við Háskóla Íslands vorið 2016. Meðal gestakennara í námskeiðinu voru Helga Kress, prófessor emeritus í almennri bókmenntafræði, Ástráður Eysteinsson, prófessor í sömu námsgrein, Björg Thorarensen prófessor við lagadeild Háskóla Íslands og Sigríður Friðjónsdóttir ríkissaksóknari. Einnig heimsóttu nemendur Hæstarétt og fræddust um starfsemi hans. Í framhaldi skipulögðu Guðrún Baldvinsdóttir, Sólveig Ásta Sigurðardóttir og Einar Kári Jóhannsson málstofu um lög og bókmenntir á ráðstefnunni NonFictionNow sem fram fór í Reykjavík í júnímánuði 2017. Meginmarkmið námskeiðsins og málstofunnar var að kanna og vekja áhuga á margháttuðum tengslum lögfræðinnar við bókmenntafræði, sagnfræði og heimspeki. Markmiðið með pessu pemahefti Ritsins er pað sama en hér birtast fjórar frumsamdar og tvær býddar greinar par sem lög og bókmenntir fléttast saman.

Í premur pessara greina er sjónum beint að íslenskum miðaldabókmenntum. Gunnar Karlsson sagnfræðingur fjallar um lög, siðareglur og bókmenntatexta frá fyrstu öldum Íslandsbyggðar sem snerta annars vegar á eignarétti höfunda á eigin textum og hins vegar peim hömlum sem tjáningu miðaldaskálda voru settar. Lára Magnúsardóttir sagnfræðingur túlkar afmarkaða kafla í Árna sögu biskups í ljósi peirra afdrifaríku pólitísku breytinga sem urðu hér á landi á síðari hluta prettándu aldar með norsku konungsvaldi og vaxandi andlegu valdi kapólsku kirkjunnar. Pá er birt íslensk pýðing á nýlegri grein eftir William Ian Miller par sem greint er hvernig lykilpersónur úr Egils sögu, Njáls sögu og Sturlu sögu beita ógnandi framkomu og hótunum í samskiptum við aðra. Höfuðáhersla er lögð á lagaprætur Hvamms-Sturlu Pórðarsonar og Páls Sölvasonar vegna Deildartungumála.

Hin býdda greinin er eftir tvo danska fræðimenn, bókmenntafræðinginn Karen-Margrethe Simonsen og lögfræðinginn Ditlev Tamm. Pau fjalla um nóvelluna Presten i Vejlbye (Vaðlaklerk) eftir danska nítjándu aldar

9 Sveinn Skorri Höskuldsson, „Um Svartfugl“, í Gunnar Gunnarsson, Svartfugl, Reykjavík: Almenna bókafélagið, 1978, bls. 227-258. 
skáldið Steen Steensen Blicher en hún byggði á pekktu sakamáli frá fyrri hluta sautjándu aldar par sem danskur prestur var ákærður og dæmdur fyrir að hafa myrt vinnumann sinn. Loks eru hér birtar tvær greinar eftir prjá unga bókmenntafræðinga sem sóttu áðurnefnt námskeið. Einar Kári Jóhannsson greinir áđurnefndar skáldsögur Steinars Braga og Vals Grettissonar í ljósi hugmynda Williams Ian Miller og fleiri fræðimanna um söguleg tengsl hefnda og réttarfars. Guðrún Baldvinsdóttir og Sólveig Ásta Sigurðardóttir skrifa aftur á móti um pað hvernig deilurnar um áðurnefndar bækur Hallgríms Helgasonar og Jóns Gnarrs tengjast lögum um tjáningarfrelsi og friðhelgi einkalífs, sem og almennari viðhorfum fólks til pessara efna. Pau Einar Kári, Guðrún og Sólveig hafa einnig býtt erlendu greinarnar í samvinnu við Láru Magnúsardóttur og Jón Karl Helgason.

Pessar sex greinar stækka vonandi umdæmi fræðilegrar umræðu á íslensku á sviði laga og bókmennta en pess má geta að á seinni árum hefur umtalsverð fræðileg umræða um höfundaréttarmál meðal annars tengst ævi og ferli Halldórs Laxness. ${ }^{10}$ Á allra síðustu árum hafa svonefnd Natansmál notið töluverðrar athygli fræðimanna á sviði sagnfræði og bókmenntafræði og er grein Helgu Kress um efnið, „Eftir hans skipun: Natansmál í ljósi sagnadansa og eftirmæla" frá árinu 2014, skýrt dæmi um rannsóknir sem hægt er að fella undir rannsóknarsvið laga og bókmennta. ${ }^{11}$ Skáldsagan

10 Hér má nefna rannsóknir á tilraunum Alpingis til að koma í veg fyrir útgáfur á íslenskum fornsögum með nútímastafsetningu sem Halldór Laxness, Ragnar Jónsson og Stefán Ögmundsson stóðu að á fimmta áratug liðinnar aldar. Sjá meðal annars Einar Arnórsson, „Stjórnarskráin og Hrafnkötlumálið“, Timarit lögfreðinga 3(1)/1953, bls. 14-26; Jón Hnefill Aðalsteinsson, „Hrafnkötluútgáfan: Aðdragandi og eftirmál“, Lesbók Morgunblaðsins 1. júní 1968, bls. 8-9 og 12; Jón Karl Helgason, „We Who Cherish Njáls saga: Alpingi as Literary Patron“, í Northern Antiquity. The Post-Medieval Reception of Edda and Saga, ritstj. Andrew Wawn, London: Hisarlik Press, 1994, bls. 143-161. Pá má nefna pá umræðu sem áðurnefnt rit Hannesar Hólmsteins Gissurarsonar um Halldór Laxness vakti á fyrstu árum pessarar aldar. Sjá m.a.: Sigurður Gylfi Magnússon, Fortíðardraumar: Sjálfsbókmenntir á Íslandi. Sýnisbók íslenskrar albýðumenningar 9, Reykjavík: Háskólaútgáfan, 2004, bls. 237-298; Helga Kress, „Meðal annarra orða: Um aðferðafræði og vinnubrögð við ritun ævisögu Halldórs Laxness 1“, Saga 42(1)/2004, bls. 187-220; Helga Kress, „Meðal annarra orða: Um aðferðafræði og vinnubrögð við ritun ævisögu Halldórs Laxness 2“, Saga 42(2)/2004, bls. 187-222; Jón Ólafsson, „Fölsuð fræði: Stuldur, svindl og uppspuni í vísindasamfélaginu“, Ritið 3/2004, bls. 103-121; Jón Karl Helgason, „Pýðing, endurritun, ritstuldur“, Íslenzk menning II: Til heiðurs Sigurði Gylfa Magnússyni, ritstj. Magnús Pór Snæbjörnsson, Reykjavík: Einsögustofnun, 2007, bls. 97-113.

11 Sbr. Helga Kress, „Eftir hans skipun: Natansmál í ljósi sagnadansa og eftirmæla Agnesar“, Saga 52(1)/2014, bls. 99-118. Sjá einnig Eggert Pór Bernharðsson, 
Náðarstund eftir Hannah Kent hefur aukið enn áhuga á pessu sögulega dómsmáli og orðið meðal annars tilefni málstofu á Hugvísindapingi vorið 2015. ${ }^{12}$ Pá má ætla að skáldsagan og umrædd fræðileg skrif hafi orðið kveikja pess að Lögfræðingafélag Íslands efndi til nýrra réttarhalda yfir morðingjum Natans nálægt vettvangi glæpsins haustið 2017. ${ }^{13}$ Sameiginlegur áhugi sagnfræðinga, bókmenntafræðinga og lögfræðinga á pessu tiltekna máli gefur til kynna að jarðvegur sé hér á landi fyrir frjóa samræðu milli pessara rannsóknarsviða.

Tvær greinar utan pema birtast í pessu hefti og, líkt og pemagreinarnar, fjalla pær bæði um efni nálægt okkur og fjarri í tíma. Hjalti Hugason ræðir um siðbótina í grein sinni „Seigfljótandi siðaskipti. Viðhorf og staðalmyndir í siðaskiptarannsóknum“. Fimm hundruð ár eru liðin um pessar mundir frá upphafi siðbótarstarfs Marteins Lúthers og er í greininni varpað ljósi á ný sjónarmið í rannsóknum á siðbótinni og afleiðingum hennar sem höfundur segir brýnar á öllum sviðum hug- og mannvísinda. Litið er svo á að siðaskiptin á Íslandi hafi falist í hægfara próun og verið, eins og Hjalti orðar pað, seigfljótandi bæði á lengdina og breiddina. Í greininni koma fram nýjar og áhugaverðar áherslur í rannsóknum á siðbótarsögunni, fjallað er um hlutverk staðalmynda og gerð grein fyrir peirri breytingu sem varð á prestastéttinni eftir að hin nýja kirkjuskipan siðbótarinnar var lögtekin.

„Friðrik, Agnes, Sigríður og Natan: Heimildagrunnur morðbrennunnar á Illugastöðum árið 1828“, Saga 51(2)/2013, bls. 9-56; Vilhelm Vilhelmsson, „Stílfært og sett í samhengi: Um heimildagildi vitnisburða í réttarheimildum“, Saga 53(1)/2015, bls. $15-45$.

12 Tveir fyrirlestrar voru fluttir á málstofunni: Ingibjörg Ágústsdóttir, „Kvenmorðingjar í kulda norðurs: Um áhrif Margaret Atwood á Burial Rites eftir Hannah Kent“ og Helga Kress „Myrkraverk: Um morðnóttina á Illugastöðum í mars 1828 frá Árbókum Jóns Espólín (1855) til skáldsögu Hannah Kent, Burial Rites (2013)“. Sjá: „Konur sem myrða: Burial Rites (Náðarstund) eftir Hannah Kent, heimildir og textatengsl“, Hugvísindastofnun, sótt 6. apríl 2018 af http://hugvis.hi.is/konur_sem_ myrda_burial_rites_nadarstund_eftir_hannah_kent_heimildir_og_textatengsl.

13 Réttarhöldin fóru fram í félagsheimilinu Hvammstanga 9. september 2017. Gestir purftu að greiða aðgangseyri og var uppselt á viðburðinn. Sigríður Friðjónsdóttir ríkissaksóknari flutti málið fyrir hönd ákæruvaldsins en verjendur voru Gestur Jónsson og Guðrún Sesselja Arnardóttir. Um málið dæmdu Ingibjörg Benediktsdóttir, Kolbrún Sævarsdóttir og Davíð Pór Björgvinsson. Sjá m.a. Kristinn H. Guðnason, „Réttað í morðmáli Agnesar Magnúsdóttur,“ DV.is 4. september 2017, sótt 6. apríl 2018 af http://www.dv.is/frettir/2017/9/4/rettad-i-mordmali-agnesarmagnusdottur/. 
Í greininni „Samlíðan og sérfræðingar“ fjallar Guðrún Steinpórsdóttir um eigindlegar rannsóknir sínar á viðbrögðum og upplifunum fólks af lestri sama texta, brotum úr tveimur skáldsögum eftir Vigdísi Grímsdóttur eins og fram kemur í undirtitli. Guðrún ræðir viðbrögð pátttakenda með hliðsjón af hugrænum fræðum, einkum skemakenningunni og hvernig mismunandi bakgrunnur peirra markar pessi viðbrögð. Niðurstöðurnar sýna að bakgrunnurinn hefur áhrif á upplifun peirra og tjáningu en einnig á tungutak og beitingu ímyndunaraflsins við að fylla í eyður verksins.

Ritið kemur nú í fyrsta sinn út í rafrænni útgáfu og par með opnum aðgangi.

Fón Karl Helgason, Lára Magnúsardóttir, Rannveig Sverrisdóttir 